\title{
Active Internationalization of Small and Medium - Sized Software Enterprises - Cases of French Software Companies
}

\author{
Maurício Floriano Galimberti *1, Raul Sidnei Wazlawick ${ }^{1}$
}

\begin{abstract}
Implementations of software production processes usually ignore organizational, market, and economical attributes of products that are to be inserted in international markets. Software engineering has begun to deal with the business aspects of software products only recently. The Guide to the Software Engineering Body of Knowledge v3.0 presents two concepts of life cycle: the software development life cycle and the software product life cycle. The second is more concerned with business issues related to software products, but research on those issues is still due. In this sense, this paper aims to answer the following question: what factors allow small and medium software enterprises to offer high value added products in order to enter and remain in the international market? This work selects four research dimensions from literature and explores a number of variables inside those dimensions, which are considered as candidates to help explaining a successful process of active internationalization. The paper presents a multiple case study that shows that although innovation, entrepreneurship, and foreign market knowledge are important dimensions for the active internationalization, networking is not as relevant as it could be thought.
\end{abstract}

Keywords: active internationalization; software product life cycle; software internationalization; French software SMEs.

Submitted: July 29th 2015 / Approved: December 2nd 2015

\section{Introduction}

In general, software production processes ignore organizational, market and economical attributes of products that are to be inserted in international markets. Business aspects began to be timidly addressed only in the past 20 years. However, they have increased significantly in the past five years. Currently, there are process models (e.g. EUP - Enterprise Unified Process (Ambler, Nalbone, \& Vizdos, 2005) that address the software life cycle in a broader view, including specification of activities that range from software maintenance to software retirement from the market, and which consider activities aimed at the business.

Software Product Lines (SPL) are committed to that idea. An SPL may be seen as a family of software systems that share common features, managed to attend the specific needs of a market segment. Those products are developed from a common core in a systematic way. Reference (Northrop, 2008) remarks that SPL may be seen as an evolution of software reuse strategies, and (Wazlawick, 2013) adds that the reuse obtained with SPL is a strategic approach for the software industry, making reuse less unpredictable and systematically incorporated to the productive processes.

Formally, Software Engineering has begun to systematize the business aspects of software product more recently with the third version of the Guide of the Software Engineering Body of Knowledge, commonly referred as SWEBOK. SWEBOK v3.0, launched in the end of 2013, presents 15 Knowledge Areas (KA), and the 12th KA is called
Software Engineering Economics. The importance of the business context for software engineering is highlighted by the presentation of two software life cycles: the software development life cycle (SDLC) and the software product life cycle (SPLC).

"A software product life cycle (SPLC) includes all activities needed to define, build, operate, maintain, and retire a software product or service and its variants. The SPLC activities of 'operate', 'maintain', and 'retire' typically occur in a much longer time frame than initial software development (the software development life cycle-SDLCsee Software Life Cycle Models in the Software Engineering Process KA). Also the operate-maintain-retire activities of an SPLC typically consume more total effort and other resources than the SDLC activities (see Majority of Maintenance Costs in the Software Maintenance KA). The value contributed by a software product or associated services can be objectively determined during the 'operate and maintain' time frame. Software engineering economics should be concerned with all SPLC activities, including the activities after initial product release" (Bourque \& Fairley, 2014).

The internationalization of small and medium-sized enterprises (SMEs) within the software sector is growing in various regions of the world, but the theories and models of internationalization have only shown a limited capacity to explain the success of SMEs in international markets. Until 2002, most studies on internationalization focused on multinational corporations. Reference (Axinn \& Matthyssens, 2002) stress that most classical studies on internationalization focus on manufacturers, especially from developed countries.

1 Department of Informatics and Statistics (INE), Federal University of Santa Catarina (UFSC), Florianópolis, Brazil

${ }^{*}$ Corresponding author: m.f.galimberti@ufsc.br 
Additionally, the process of internationalization of a company may be active or passive. Roselino defines active internationalization as the ability of companies to become proactively able to sell and to remain selling their products in foreign markets (Roselino, 2006). Further investigation on the active internationalization of SMEs offering innovative high technology products is still due. Innovation should also be a guideline for internationalization in the software industry (Ronkko, Ojala, \& Tyrvainen, 2013). This paper covers this gap by studying the active internationalization of software SMEs aligned with the tendencies presented in SWEBOK v3.0.

France, as a mainstream country in terms of technology, was chosen for the investigation. Even though the United States is the biggest software market, estimated in US\$112.2 billion in 2008, other countries with a similar international behavior should also be observed (Datamonitor, 2008b) ${ }^{1}$. This is the case of Germany, France and the United Kingdom, in which the internationalization is usually active, because those countries do not appear in the ranking of the 10 greatest outsourcing providers, although they respectively shared $29.8 \%, 15.8 \%$ and $20.8 \%$ of the European software market in 2008. This means that together they respond for $66.4 \%$ of the market in Europe, with an income of US\$91.5 billion (Datamonitor, 2009) (Datamonitor, 2008a).

This study is concerned about the high added-value software sector. Since this sector can offer greater opportunities for companies from developing countries, it is relevant to learn from the behavior of companies from developed countries, such as France. Therefore, the main research question of this paper is: what are the factors that enable high added-value software SMEs to enter and remain in the international market? Based on a literature review, we propose a model with four research dimensions and a number of candidate variables considered relevant to influence a successful process of active internationalization. The four dimensions are innovation, entrepreneurship, relationship networks, and knowledge about the foreign market.

This article has six further sections. The next section presents the theoretical framework and the current models of internationalization. The third section presents the model for active internationalization of software SMEs. The fourth section presents the adopted research method, and the fifth one offers a description of three case studies of internationalization in French software SMEs. The sixth section discusses some results under the light of the research propositions. The last section is reserved for final considerations and future studies.

\section{Research Background}

Although there are various classifications on internationalization theories, in this study, they are distinguished as general or specific. The general models and theories of internationalization do not distinguish small and large companies in the process of expansion into foreign markets. Therefore, they usually explain the internationalization phenomenon from the point of view of large multinationals, especially manufacturers (Andersen \& Buvik, 2002). General models have received criticism from numerous authors, such as Andersson (Andersson, 2000), Axinn e Matthyssens (Axinn \& Matthyssens, 2002), and Johanson and Vahlne (Jan Johanson \& Vahlne, 2003). They argue that there is a need for new models of internationalization that consider current markets and technology dynamics, with faster internationalization processes than those that existed when most of the general models were formulated.

The specific models and theories of internationalization, on the other hand, focus on the features of small companies. Those features were selected for a detailed analysis, which led to the identification of the variables presented in the research model.

Regarding the scope of this paper, the theoretical discussion focuses on specific models and theories that were analysed in order to search for those that explain the active internationalization of SMEs in the area of innovative and high technology products and services. This paper focus on the process of active internationalization and its success. In this context, a successful company is one that is not shrinking and is self-sustained by its international activities. This research looks for the factors that have actual impact on the success of the internationalization of that kind of company.

The Innovation-Based Models of Internationalization (I-Models) are considered as specific models. Although those models date from almost the same era as the general models, they consider the need to differentiate the size of the company during the internationalization process. However, similarly to general models, they consider internationalization to be a process that occurs in stages, which represents a feature common to main I-Models (Bilkey \& Tesar, 1977) (Cavusgil, 1980) (Czinkota, 1982) (Reid, 1981). Those models differ from one another mainly in terms of the number of stages included and their respective descriptions. Nonetheless, there are no substantial differences in the essence of the processes. The contribution of the I-Models is significant in two aspects: (1) because they differentiate the internationalization process in SMEs and (2) they offer innovation as an explanation for internationalization. In the first aspect, (Reid, 1981) suggests research on exports and other entry modes in foreign markets. Under these circumstances, the SMEs should pay more attention to the individual characteristics of the entrepreneur and decision maker, and on how those characteristics affect the exporting behavior. Regarding the second aspect, the I-Models consider the internationalization process as an innovative strategic initiative.

The Networks Model (Jan Johanson \& Vahlne, 2003) is an extension to the Uppsala Model (J. Johanson \& Vahlne, 1977); both models were proposed by Johanson and Vahlne. Even though it is based on large multinational companies, the Networks Model explains that the decision making process regarding internationalization activities is directly or indirectly determined by what occurs in local business networks. That knowledge may be applied to international markets. Reference (Jan Johanson \& Vahlne, 2003) also mention that the model can explain a great deal about the growth process of small firms that undertake activities in foreign markets. Chetty and Holm state that, as a strategy, the

1 Datamonitor conducted this research until 2009 only. 
company should establish relationships in new countries (international extension), or increase its participation in previously established markets, or still integrate its positions in networks in different countries (international integration) (Chetty \& Blankenburg Holm, 2000).

The Theory of International Entrepreneurship explains the international expansion of new and established SMEs that need to expand their activities to other markets. Reference (Andersson, 2000) claims that the process of internationalization is not an activity that can be separated from the other ones; it is rather a consequence of the company's strategy. That would characterize strategy as an entrepreneurial action.

There is also an approach denominated as "Born Global", which was first used by (Rennie, 1993). Born Global firms are SMEs that are constituted with a view on internationalization, or, at least, which begin to act internationally after the first few years in the domestic market. The Born Global phenomenon is still contested, based on the argument that general theories and models of internationalization could explain. However, a growing number of studies identify special characteristics to such firms, as, for example, (Phillips McDougall, Shane, \& Oviatt, 1994), (Madsen \& Servais, 1997), (Harveston, Kedia, \& Davis, 2000), (Sharma \& Blomstermo, 2003), and (Chetty \& Campbell-Hunt, 2004). Consequently, the central characteristics that define a Born Global SME are considered to be the age of the company when it begins its international activity and the share of its revenue obtained from international markets.

\section{Model of Active Internationalization of Software SMEs}

Many factors influence high-value added software products and services positioning in the global market; and one of them is innovation. Both passive and active internationalization are related to innovation and to the qualification of professionals from these companies. Roselino mentions that in an active process of internationalization, the process of innovation is originated from the main corporate headquarter (Roselino, 2006). Moreover, the software products developed by highly qualified software engineers are characterized by the addition of a high-value. An example of an active process of internationalization is the practice of the North American software industry, which dominates the Internet market.

On the other hand, the passive process of internationalization consists on rendering services of low or average value added; it does not depend on the outsourcing country to have high standards in software engineering. Many companies at India are examples of the passive process of internationalization.

"The factors that influence the internationalization process of SMEs of software and related services depend on the stage of development of the firm and its relation with innovation as well as the proper capacities of the entrepreneur" (Galimberti \& Dorion, 2011). The specific internationalization approaches normally refer to SMEs, the entrepreneur, their services and innovations, but there is no research, established model, or theory compiling all these subjects and addressing them related to a specific sector such as the software industry.

The approaches aforementioned proposed a number of features for the analysis of active internationalization. Based on these features, (Galimberti \& Dorion, 2011) have established the model that summarize the dimensions and candidate variables that could contribute to the process of active internationalization, which is adapted in Fig. 1.

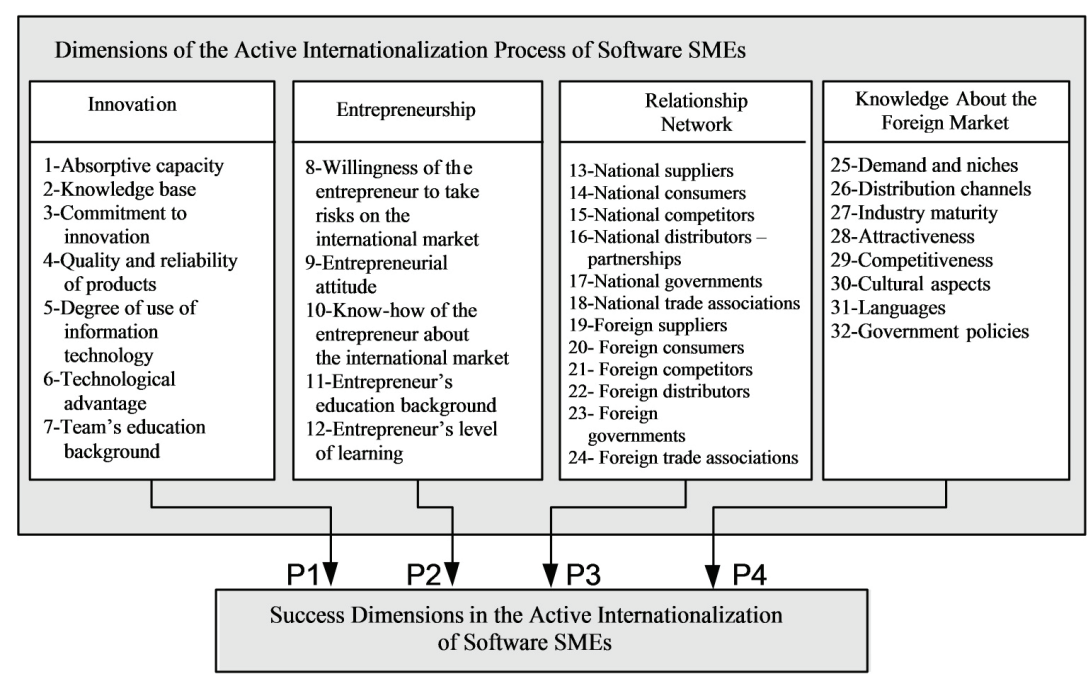

In Fig. 1, four dimensions were defined with 32 empirical variables. The dimensions are innovation, entrepreneur, business networks, and foreign market knowledge. Their study searched for evidences to confirm, or not, the following research propositions: 
P1: The degree of service or product innovation influences the success of the process of active internationalization of a software SME. This proposition deals with the influence of innovation on the process of active internationalization of the SMEs, which is studied through the variables of the innovation dimension of the model.

P2: The attributes of entrepreneurship influence the success of the process of active internationalization of a software SME. This proposition refers to the entrepreneur's attributes for the success of the internationalization process of the company, which are studied through the variables of the entrepreneurship dimension of the model.

P3: The networks maintained by a software SME and related services influence the success of active internationalization. This proposition refers to the implications and the impact of the configuration of networks on active internationalization process, which are studied through the variables of the network dimension of the model.

P4: The knowledge of foreign markets influences the degree to which software SMEs are successful in obtaining active internationalization. This proposition deals with the configuration of the foreign market knowledge as determinant to the internationalization process, which is being studied through the variables of the foreign market knowledge dimension of the model.

Each proposition is discussed along with the presentation of the results.

\section{Research Method}

The research strategy of this study is qualitative. The object of the study is composed by three leading French software companies, which performed a successful process of active internationalization. The investigation method consists of empirically collecting data by means of in-depth semi-structured basic interviews with manage- ment people from each company. A secondary data collection is based on a systematized research including books, journals, newspapers, magazines, dissertations, and theses, among other sources. Case studies allow the use of multiple evidence sources as an extensive research strategy (Yin, 2013). With data triangulation, it is also possible to dedicate attention to the potential problem of construct validity, because more evidence sources provide different evaluations for the same phenomenon.

The criteria that define the selection process of the software companies to be studied are the following:

- $\quad$ Each company must be characterized as an SME as defined by the European Commission;

- $\quad$ Each company must have business results from other countries and must be sustainable with its activities abroad;

- Each company must have had international activities for more than two years;

- $\quad$ Each company must have a total income compatible with SMEs average income, regardless the way the company accessed international markets; and

- Each company must have autonomy regarding the high value products or services it offers, meaning it carries out active internationalization.

The research protocol was initially implemented in one pilot case study in France. The quality of the data obtained justified keeping the pilot case study and the same structure of interviews for the two other cases.

To comply with the research protocol, two entrepreneurs and a manager in each French SME were interviewed, showing the business profile shown in Table 1. The data set is organized regarding the scope of the paper and the analysis presented in the current section.

Table 1. Software SMEs research in France and selection criteria

\begin{tabular}{ccccc}
\hline French Software SME & №. of Employees & Annual Income & \% of International Income & Opening / International \\
\hline FRAN & 55 & $€ 5$ million & $40-50 \%$ & $2000 / 2000$ \\
\hline EDIT $^{*}$ & 55 & $€ 9$ million & $5 \%$ & $2000 / 2004$ \\
\hline LILI $^{*}$ & 25 & $€ 2.7$ million & $10 \%$ & $1985 / 1987$ \\
\hline$*$
\end{tabular}

${ }^{\star}$ Fictitious names

The classification of the French companies took into consideration the definitions of the European Commission (Liidanen, 2003): an SME must not have more than 250 employees, must not be a branch of an industrial group, and the volume of its annual business must not exceed $€ 50$ million. Within this category, a small company employs less than 50 people and the annual business volume does not exceed $€ 10$ million, and a micro company employs less than 10 people and the annual business volume does not exceed $€ 2$ million.

\section{Results}

The three cases studied in this work are described in the following subsections.

\section{A. The Fran Case}

The first case, called here "Fran", is a French private capital company that develops software for specific business segments that search and 
organize specialized documents and information. Seven entrepreneurs founded the company in 2000 , and currently they own $30 \%$ of the company shares.

Fran, which was created by entrepreneurs with extensive experience in the software industry, acts specifically in the development of software technology with data mining, information search, and indexing capacities, which are also commonly known as search engine or search machine technology. Fran holds the full property and design rights over its products. In 2007, the company's total revenue reached $€ 5$ million, and the percentage of revenue from abroad was in the order of $40 \%$ to $50 \%$. This percentage has been relatively stable since the year of its foundation.

In relation to the size of Fran and the market in which it acts, it was said that the company, "[...] while quite young, is more than a startup company, this is an SME". However, the General Director considers that in relation to the market and the sector, "[...] we are big, we are leaders in Europe and currently world leaders after the acquisition of two competitors. We have been leaders in terms of technology for some time and now we are also market leaders".

Fran may be classified in the category of born global since from its first year it began to sell its products in Germany, established a subsidiary in Switzerland and a sales office in Italy, along with France. So, "[...] from the beginning Fran was conceived of as a European company, with revenue coming also from Italy, Switzerland and Germany. Two years after founding the company, luckily, we got our first customers from the U.S. In 2004 the North American office was established to prospect for clients, which became a subsidiary in 2006. These were the main countries, but throughout this process of internationalization commercial contacts were maintained in the United Kingdom, Holland and Belgium".

Fran choose to work on four segments, depending on an analysis of the targeted external market. The segments are: (1) pharmaceutical, (2) publishing/press, (3) security for the public sector, industry and banks, and (4) sale of technology, or OEM (Original Equipment Manufacturer), to other software companies.

In France, the strategy is to cover all four segments, due to the existing demand and the size of the company structure. In other countries, where it has subsidiaries, such as Germany and the U.S., one or two segments are pursued, in these cases the pharmaceutical and the publishing/press industries.

Business functions are distributed according to the strategic and operational needs. The strategic management is located in Paris. Product development takes place in Paris and Grenoble. There is no development in other countries, and usually, the software is written in English. Depending on the location this can be adapted to Italian, French and German, if needed, but the process was said to be fairly simple. As a result, the products and services that are developed and sold are identical in all countries.

\section{B. The Edit Case}

The company whose pseudonym here is "Edit" was founded in May 2000 by two entrepreneurs, who currently are the only shareholders and hold the posts of chairperson and chief executive officer. Edit is a limited company with 55 employees and had a revenue of $€ 9$ million in $2007,5 \%$ of which came from its activities abroad.

In France, Edit is characterized as a software concepteur-editeur, which means that it designs, develops and sales software products. It produces software to be used in the automatic generation of other software, which means it could fit in the segment of Computer-Aided Software Engineering (CASE) tools, with the important difference that while CASE tools are intended for developers, Edit's products are targeted at business analysts. Edit also sales a CASE tool from the United States, but this is not the focus of its activity.

To consolidate Edit was a very difficult and troubled process. In 2001, only one year after the company was founded, the markets suffered a blow, due to the $9 / 11$ attacks in the United Sates. In 2003, a new prototype was conceived and designed, and they approached the French Ministry of Research, driven by the innovative aspects incorporated into the product, as the chairperson recalls: "So they told us, yes, cool, this product is very innovative, there is nothing similar in the rest of the world. So they lent us the money to complete the project, and now we are paying it back." This happened in 2004, and thereafter the firm effectively began to internationalize. He adds that "[...] now, it is okay, the product is good, we have started to internationalize to Anglo-Saxon countries." Today Edit has operations in France, the United States of America and the United Kingdom.

The company's strategy to access international markets, especially the American market, consisted of two stages: first, one of the entrepreneurs went to the United States to present the product. The reaction of people was noted to see whether the concept was adapted to the market and whether the presentation and marketing method were suited to the market, in order to implement any necessary adjustments. In the second stage, potential client companies in the United States that also had businesses in France were surveyed, and a search was made for partners and distributors for prospecting and selling software in the United States of America.

Contacts with the North American market are usually conducted online, using a teleconference tool, speaking in French and English to facilitate international communication. The chairperson said that the company does not seek to reach every country; they are interested only in those with greater demand, such as the United States. Even in those countries, the strategy chosen is to find and retain distributors. He added, "I do not want to manage 1000 people, but instead I want to have resellers. In the United States, there are partners. Our partner in the United States is a representative".

The firm's specific functions are geographically distributed. The central and commercial base is located in Suresnes, in the metropolitan 
area of Paris. Support for development is carried out in Pessac, in the Bordeaux region. The teleconferences and technical seminars, which are a strong mechanism for communication and company marketing, along with development, are conducted from Casablanca (Morocco), where Edit's R\&D laboratory is located.

\section{The Lili Case}

The last company in the study goes by the pseudonym "Lili". Two entrepreneurs founded the company in 1985. Its focus is on developing and marketing software and statistical support for scientific research. Currently the company has 25 people on its staff, with 16 in Annecy and 9 in Grenoble. Lili is characterized as a small business, both by the number of employees and by terms of revenue, which was $€ 2.7$ million in 2007 . The entrepreneur that was interviewed pointed out that the percentage of revenue coming from abroad is around $10 \%$ to $15 \%$, with a small growth of around $2 \%$ each year: "You can see, it was €191 thousand in 2005, €202 thousand in 2006, and €260 thousand in 2007."

The entrepreneur points out that "[...] these values are in direct sales to consumers who access Lili's site in order to make a purchase." There is still a part, the remainder, which represents sales through resellers in other countries. "Most come from Switzerland, probably because it is a Francophone country, where we have sellers, then come Germany, Brazil, Belgium, Senegal, Morocco and Ireland, where we have the same types of partners."

Activities abroad began, in the words of the entrepreneur, "[...] as an opportunity and not by our efforts. This happened, almost from the start in 1987 in Turkey". In 1990, they began to sell in the United Kingdom, moving to another distributor in 1996. In 1995, activities began in Brazil. In the year 2000, they reached access to the German market and hence the business began to expand to other countries.

One of the dimensions highlighted as being crucial for the expansion of the company into international markets was a business strategy based on low price and mass distribution. The initial projects began as result of the academic experience of one of the entrepreneurs, moving on to larger markets due to the demand and the opportunities that arose, which caused the company to design a software application for the market in general.

After a certain period, the strategy changed from one of opportunism to one of voluntarism, that is, they started to seek partners and international distributors. As the entrepreneur says, "the search now is for an existing company, which already has activities in the sector of interest, that may even distribute for a competitor, and that will put our software into its product portfolio."

A great difficulty found both at the founding of the company and at the beginning of the internationalization process concerns obtaining financial investment. He stressed that this is no longer a problem for Lili to access other markets because "we have money", but it is very hard to start a small business, let alone going international.

\section{Discussion}

A description of each case, actually summarized for this paper, shows that product innovation as well as the rights resulting from its development are characterized as an active process of internationalization. The data analysis of each case enhances the evidences identified from the synthesis of the results through the attributes of the research model, dealing with each variable in terms of positive or negative intensity of citation during the process of data collection. The intensity degree, although qualitative, was assigned based on several systematic considerations presented elsewhere (Galimberti, 2009) whose presentation unfortunately would not fit in this paper.

\section{A. Proposition P1}

The first dimension refers to the innovation attributes, and Table 2 presents the results that are interpreted in terms of Proposition P1. This proposition deals with the influence of innovation on the process of active internationalization of the SMEs and it may be analyzed through the variables of Table 2.

Table 2. Dimensions of INNOVATION - Indicator Intensity

\begin{tabular}{|l|c|c|c|c|}
\hline \multirow{2}{*}{ Variables } & \multicolumn{3}{c|}{ Cases } & \multirow{2}{*}{$\begin{array}{c}\text { Partial } \\
\text { Conclusions }\end{array}$} \\
\cline { 2 - 5 } & Fran & Edit & Lili & +- \\
\hline 1-Absorptive capacity & + & +- & - & +- \\
\hline 2-Knowledge base & + & + & +- & + \\
\hline 3-Commitment to innovation & + & + & +- & + \\
\hline $\begin{array}{l}\text { 4-Quality and reliability of } \\
\text { products }\end{array}$ & + & + & + & + \\
\hline $\begin{array}{l}\text { 5-Degree of use of information } \\
\text { technology }\end{array}$ & +- & +- & - & +- \\
\hline $\begin{array}{l}\text { 6-Technological advantage } \\
\text { 7-Team's educational } \\
\text { background }\end{array}$ & + & + & +- & + \\
\hline
\end{tabular}

Captions: (x) no intensity; (-) low intensity; (+ -) medium intensity; and (+) high intensity.

The three French companies operate in highly complex software segments that demand the high quality and reliability from their software, which is consistent with the needs of application sectors. The technological differential is present in the three software companies, being more evident in the Fran company, which also has the best results in terms of international revenues. The educational level of the staff was quite high, both among those involved in management activities and in the teams of software developers, which, in the case of Fran, also included specialists in segments of the software application. These variables help to confirm the high commitment of the enterprises to innovative activities, even depending on it in order to find a niche in markets already dominated by larger companies. 
Given their characteristics, Fran and Edit may be classified as Born Global, especially because they were established with an eye on the international market. Additionally, the above aspects confirm for the three companies what the Born Global Perspective claims regarding the importance of quality products for internationalization, as well as technological advantage, which is also advocated by the Theory of International Entrepreneurship. The high-level staff training appears to be closely related to the innovation of products and that supports the proposition that it has an important role in active internationalization.

Proposition 1 is confirmed in the French cases: innovation proved to be crucial to the SMEs active internationalization process as shown by the intensity of the firms commitment to innovation, concern with the quality and reliability of their products, search for technological advantage and high qualification of their staff at all stages of the internationalization process, and an average impact of absorptive capacity. The variable related to the creation and maintenance of knowledge bases was the only variable that appeared only in an advanced stage of internationalization.

\section{B. Proposition P2}

The second proposition refers to the entrepreneur's attributes for the success of the active internationalization process of the company, as presented at Table 3 .

In all cases, the French entrepreneurs proved to have the main characteristics required for the internationalization process.

Table 3. Dimensions of ENTREPRENEURSHIP - Indicator Intensities

\begin{tabular}{|l|c|c|c|c|}
\hline \multirow{2}{*}{ Variables } & \multicolumn{3}{c|}{ Cases } & \multirow{2}{*}{$\begin{array}{c}\text { Partial } \\
\text { Conclusions }\end{array}$} \\
\cline { 2 - 4 } & Fran & Edit & Lili & + \\
\hline $\begin{array}{l}\text { 8-Willingness of the } \\
\text { entrepreneur to take risks on } \\
\text { the international market }\end{array}$ & + & + & +- & + \\
\hline 9-Entrepreneurial attitude & + & + & + & + \\
\hline $\begin{array}{l}\text { 10-Know-how of the } \\
\text { entrepreneur about the } \\
\text { international market }\end{array}$ & + & +- & - & + \\
\hline $\begin{array}{l}\text { 11-Entrepreneur's educational } \\
\text { background }\end{array}$ & + & + & + & + \\
\hline $\begin{array}{l}\text { 12-Entrepreneur's level of } \\
\text { education }\end{array}$ & + & + & +- & + \\
\hline
\end{tabular}

Captions: (x) no intensity; (-) low intensity; (+ -) medium intensity; and $(+)$ high intensity.

Regarding the willingness of the entrepreneurs to take risks in the international market, it is evident in the case of the entrepreneurs from Edit and Fran. They had the initiative to take their products outside France and seek investments to boost their international position.

The entrepreneurs of the three firms have an equivalent level of edu- cation. However, Lili's entrepreneur did not have formal education in computer science. It should be further investigated whether such aspect influenced on the late internationalization of Lili, because the entrepreneur, with a different background maybe was afraid to invest on other markets while the company was beginning.

\section{Proposition P3}

The third propositon concerns to the impact of networking on the process of active internationalization. Based on data presented at Table 4 , it can be said that only few of the commonly referred types of networks contribute to the internationalization process.

Table 4. Dimensions of RELATIONSHIP NETWORK - Indicator Intensities

\begin{tabular}{|l|c|c|c|c|}
\hline \multirow{2}{*}{\multicolumn{1}{|c|}{ Variables }} & \multicolumn{3}{c|}{ Cases } & \multirow{2}{*}{$\begin{array}{c}\text { Partial } \\
\text { Conclusions }\end{array}$} \\
\cline { 2 - 5 } & Fran & Edit & Lili & $\mathrm{x}$ \\
\hline 13-National suppliers & $\mathrm{x}$ & - & $\mathrm{x}$ & + \\
\hline 14-National consumers & + & + & + & $\mathrm{x}$ \\
\hline 15-National competitors & $\mathrm{x}$ & $\mathrm{x}$ & $\mathrm{x}$ & + \\
\hline $\begin{array}{l}\text { 16-National distributors - } \\
\text { partnerships }\end{array}$ & + & + & $\mathrm{x}$ & $\mathrm{x}$ \\
\hline 17-National governments & +- & $\mathrm{x}$ & $\mathrm{x}$ & $\mathrm{x}$ \\
\hline 18-National trade associations & - & $\mathrm{x}$ & - & - \\
\hline 19-Foreign suppliers & $\mathrm{x}$ & + & $\mathrm{x}$ & $\mathrm{x}$ \\
\hline 20-Foreign consumers & + & + & - & + \\
\hline 21-Foreign competitors & $\mathrm{x}$ & $\mathrm{x}$ & $\mathrm{x}$ & $\mathrm{x}$ \\
\hline $\begin{array}{l}\text { 22-Foreign distributors - } \\
\text { partnerships }\end{array}$ & +- & - & +- & +- \\
\hline 23-Foreign governments & - & $\mathrm{x}$ & $\mathrm{x}$ & $\mathrm{x}$ \\
\hline 24-Foreign trade associations & $\mathrm{x}$ & $\mathrm{x}$ & $\mathrm{x}$ & $\mathrm{x}$ \\
\hline
\end{tabular}

Captions: (x) no intensity; (-) low intensity; (+ -) medium intensity; and $(+)$ high intensity.

The relationships maintained by the French companies within their territory are limited to domestic consumers, national distributors (partnerships) and in lesser degree with professional associations. Consumers play a fundamental role for French companies regarding the pursuit of ideas for implementing innovative features in software products. In terms of French distributors, partnership engagement to develop technology is considered more important than distribution networks, as suggested by the Networks Model. Involvement with professional associations proved to have no influence on the success of internationalization.

In relation to international involvement, the French companies have shown little commitment to establish relationships through networks except with international customers, which is more evident in the two 
companies that maintain offices or subsidiaries abroad. These companies also have relationships with international distributors at a more advanced stage of internationalization, while the company that developed actions with foreign distributors from the beginning of the process has little involvement with international customers. Therefore, for these French SMEs, networking is important only with a few relevant stakeholders.

\section{Proposition P4}

This proposition is concerned with the configuration of the knowledge about the foreign market as determinant to the internationalization process; it is analyzed through the variables of Table 5.

Half of the variables within this dimension suggest similarities between the French companies, but they were all considered relevant from the beginning of the internationalization of these companies. It was mentioned that demand and market niches, as well as maturity and attractiveness of markets, were thoroughly considered by entrepreneurs who have built up their business thinking of selling their products in the international market.

According to definitions from Rennie (Rennie, 1993), McDougall (McDougall, 1989), and Sharma and Blomstermo (Sharma \& Blomstermo, 2003), the Born Global phenomenon may be applied to the Fran and Edit companies. However, the emphasis on knowledge of the external market was not found in the Born Global literature, except in relation to market niches. The three companies have also emphasized a concern regarding cultural aspects of the countries where they intend to act and minimize the importance of the foreign language. In this sense, it is important to highlight that these people, who are part of the French companies since their foundation, are fluent in English. Nevertheless, this was not a resource that worried them, being that English is considered the main means of communication by the entrepreneurs, even in countries where other languages are spoken, such as Germany or Italy.

The aspects related to competitiveness and distribution channels have demonstrated a moderate degree of influence on the success of the French companies, two of which maintain their own subsidiaries in other countries and, with their growth, are now considering using distributors abroad. The only variable with low intensity is related to the knowledge of government policies, only highlighted by the Fran Company, which develops software aimed at public safety.

Table 5. Dimensions of KNOWLEDGE ABOUT THE FOREIGN MARKET- Indicator Intensities

\begin{tabular}{|l|c|c|c|c|}
\hline \multirow{2}{*}{\multicolumn{1}{|c|}{ Variables }} & \multicolumn{3}{c|}{ Cases } & \multirow{2}{*}{$\begin{array}{c}\text { Partial } \\
\text { Conclusions }\end{array}$} \\
\cline { 2 - 5 } & Fran & Edit & Lili & + \\
\hline 25-Demand and niches & + & + & +- & + \\
\hline 26-Distribution channels & - & - & +- & +- \\
\hline 27-Industry maturity & + & + & +- & + \\
\hline
\end{tabular}

\begin{tabular}{|l|c|c|c|c|}
\hline \multirow{2}{*}{ Variables } & \multicolumn{3}{c|}{ Cases } & \multirow{2}{*}{$\begin{array}{c}\text { Partial } \\
\text { Conclusions }\end{array}$} \\
\cline { 2 - 4 } & Fran & Edit & Lili & + \\
\hline 28-Attractiveness & + & + & +- & + \\
\hline 29-Competitiveness & + & - & +- & +- \\
\hline 30-Cultural aspects & + & + & + & + \\
\hline 31-Languages & + & - & +- & +- \\
\hline 32-Government policies & +- & $\mathrm{x}$ & $\mathrm{x}$ & - \\
\hline
\end{tabular}

Captions: (x) no intensity; (-) low intensity; (+ -) medium intensity; and (+) high intensity.

\section{Final Considerations}

The four dimensions explored in this research are straightly related to the software engineering processes, especially those included in the SPLC, as mentioned by the SWEBOK v3.0. Most of the 32 candidate variables investigated are related to topics included in the knowledge area of software engineering economics in SWEBOK v3.0: among others, the topic on decision-making process, in the section of software engineering economics fundamentals. Many topics in life cycle economics, such as product life cycle and project life cycle, investment decisions, planning horizon, price and pricing, cost and costing, and replacement and retirement decisions are also included both in SWEBOK and this research.

Amongst the reviewed theories and approaches, the Born Global concept has a lot in common with the characteristics of French software SMEs and, therefore, it can be used to explain their active internationalization process. It can also be concluded that the degree of innovation of the products the SMEs sell in foreign markets can determine the level of success of their internationalization process. The main characteristics of the I-Models suggest that the decision to internationalize should be considered a specific process of innovation within the company. It can be seen from this study that certain features, such as knowledge and innovation, are directly related to quality and reliability, technological edge and the use of partnerships (networks) as a core strategy.

There is a strong similarity between the approaches taken by this type of entrepreneur, with the variables identified in a Born Global perspective. However, the ones that refer to innovativeness, product quality and reliability and technological edge, as well as the variables related to the experience of the entrepreneur, are present in both the Born Global perspective and in the I-Models.

In relation to the attributes of the entrepreneur, they are likely to have an impact on the success of the process of internationalization of the SMEs. The relevance given to the entrepreneur is evident in each of the specific approaches considered in this article as reference to the Theory of International Entrepreneurship and the Born Global perspective. Concerning International Entrepreneurship, the preferences of the entrepreneur can be added as a variable within the I-Models and Born Global perspective, in order to structure a construct related 
to the role of the entrepreneur in the process of internationalization. This paper shows that many studies have highlighted the role of the entrepreneur in the process of internationalization of a company. Together with the concept of innovation as a determinant strategy for the internationalization process, they are shown to constitute the most relevant research dimensions for the success of the active process of internationalization of the software SMEs.

The main discrepancy found comparing the results with the preliminary research model and literature is related to the engagement with national distributors (variable 16). The companies studied shown large involvement with national technological partners, as predicted by the Born Global Perspective, but not with national distributed, as predicted by the Networks Model. Besides that, more than half variable that deal with network involvement were not confirmed or shown low intensity.

Therefore, the analysis of the results, in relation to the variables identified in the model shown in Figure 1, leads to the conclusion that to be successful in its process of internationalization an SME must: (1) have the capacity to innovate, (2) be a leader with high level of entrepreneurship, (3) have the capacity to insert itself in relevant networks, and (4) have knowledge of the foreign market with different specificities due to the evolution of the international activities.

In this sense, it was attempt to find a set of theories and models that would describe and bring to light the degree of agreement with the four highlighted dimensions. It can be stated that the four research dimensions and their variables fulfilled the research objectives of finding which variables may contribute to the success of the SMEs in their pursuit of continuous business with innovative products in international markets. This study is exploratory, since it opens new thinking about the importance and the feasibility of implementing active internationalization processes in SMEs. Although the realities of only three companies were explored, the value of this study rely on its potential for generalization. Despite a generalization based on three case studies cannot be completely assured, there are indications that these findings might provide basis not only for small and medium companies with business projects in software but also for other innovative high technology products. However, the generalization of this study for developing countries may not be so assertive; thus, we suggest future studies, especially with samples of small firms from developing countries, to test the validity of the proposed model. Additionally, broader studies are suggested to evaluate internationalization process, as well as the organizational results generated as result of the implementation of these strategies, with a greater number of companies.

\section{Acknowledgment}

This work was partially supported by Coordenação de Aperfeiçoamento de Pessoal de Nível Superior (CAPES).

\section{References}

Ambler, S. W., Nalbone, J., \& Vizdos, M. J. (2005). The Enterprise Unified Process: Extending the Rational Unified Process. Prentice Hall
PTR. Retrieved from https://books.google.com/books?id=r-hiQgAACAAJ\&pgis $=1$

Andersen, O., \& Buvik, A. (2002). Firms' internationalization and alternative approaches to the international customer/market selection. International Business Review, 11(3), 347-363. http://doi. org/10.1016/S0969-5931(01)00064-6

Andersson, S. (2000). The internationalization of the firm from an entrepreneurial perspective. International Studies of Management and Organization. Retrieved from http://www.scopus.com/inward/ record.url?eid=2-s2.0-0012814740\&partnerID=tZOtx3y1

Axinn, C. N., \& Matthyssens, P. (2002). Limits of internationalization theories in an unlimited world. International Marketing Review, 19(5), 436-449. http://doi.org/10.1108/02651330210445275

Bilkey, J., \& Tesar, G. (1977). The export behavior of smaller Wisconsin manufacturing firms. Journal of International Business Studies1, 9(1), 93-98.

Bourque, P., \& Fairley, R. E. (2014). Guide to the Software Engineering Body of Knowledge (SWEBOK(R)). IEEE Computer Society.

Cavusgil, S. (1980). On the Internationalization Process of Firms. European Research, 8, 273-281.

Chetty, S., \& Blankenburg Holm, D. (2000). Internationalisation of small to medium-sized manufacturing firms: A network approach. International Business Review, 9(1), 77-93. Retrieved from http://www.scopus.com/inward/record.url?eid=2-s2.00034134949\&partnerID=tZOtx3y1

Chetty, S., \& Campbell-Hunt, C. (2004). A Strategic Approach to Internationalization: A Traditional Versus a "Born-Global" Approach. Journal of International Marketing, 12(1), 57-81. Retrieved from http://www.scopus.com/inward/record.url?eid=2-s2.01642387422\&partnerID=tZOtx3y1

Czinkota, M. (1982). Export development strategies: US promotion policy. Retrieved from https://scholar.google.com scholar?cluster $=7373618366045398112 \&$ hl $=$ en \&oi $=$ scholarr $\# 0$

Datamonitor. (2008a). Software in France: Industry Profile 2008. Retrieved from https://www.datamonitor.com/

Datamonitor. (2008b). Software in United States: Industry Profile 2008. Retrieved from https://www.datamonitor.com/

Datamonitor. (2009). Software in Europe: Industry Profile 2008. Retrieved from https://www.datamonitor.com/

Galimberti, M. F. (2009). Fatores de Sucesso na Internacionalização Ativa de Pequenas e Médias Empresas de Software: estudo de casos do Brasil e da França. Universidade Federal do Rio Grande do Sul.

Galimberti, M.F., \& Dorion, E. C.H.(2011). Active internationalisation 
of Brazilian SMEs from the software sector. International Journal of Management and Enterprise Development.

Harveston, P. D., Kedia, B. L., \& Davis, P. S. (2000). Internationalization of Born Global and Gradual Globalizing Firms: The Impact of the Manager. Advances in Competitiveness Research, 8(1), 92. Retrieved from https://www.questia.com/library/journal/1P3-68959937/ internationalization-of-born-global-and-gradual-globalizing

Johanson, J., \& Vahlne, J. (1977). The internationalization process of the firm: a model of knowledge and increasing foreign market commitments. Journal of International Business Studies, 8(1), 23-32.

Johanson, J., \& Vahlne, J.-E. (2003). Business Relationship Learning and Commitment in the Internationalization Process. Journal of International Entrepreneurship, 1(1), 83-101. http://doi. org/10.1023/A:1023219207042

Liidanen, E. (2003). Concerning the definition of micro, small and medium-sized enterprises. Official Journal of the European Union. Retrieved from http://eur-lex.europa.eu/LexUriServ/LexUriServ. do?uri=OJ:L:2003:124:0036:0041:EN:PDF

Madsen, T. K., \& Servais, P. (1997). The internationalization of Born Globals: An evolutionary process? International Business Review, 6(6), 561-583. http://doi.org/10.1016/S0969-5931(97)00032-2

McDougall, P. P. (1989). International versus domestic entrepreneurship: New venture strategic behavior and industry structure. Journal of Business Venturing, 4(6), 387-400. http://doi. org/10.1016/0883-9026(89)90009-8

Northrop, L. (2008). Software Product Lines Essentials (No. 152132612). Pittsburgh. Retrieved from http://www.sei.cmu.edu/library/ assets/spl-essentials.pdf
Phillips McDougall, P., Shane, S., \& Oviatt, B. M. (1994). Explaining the formation of international new ventures: The limits of theories from international business research. Journal of Business Venturing, 9(6), 469-487. http://doi.org/10.1016/0883-9026(94)90017-5

Reid, S. D. (1981). The Decision-Maker and Export Entry and Expansion. Journal of International Business Studies, 12(2), 101-112. http://doi.org/10.1057/palgrave.jibs.8490581

Rennie, M. W. (1993). Born Global. The McKinsey Quarterly, (4), 45. Retrieved from https://www.questia.com/library/ journal/1G1-15424561/born-global

Ronkko, M., Ojala, A., \& Tyrvainen, P. (2013). Innovation as a driver of internationalization in the software industry. In 2013 International Conference on Research and Innovation in Information Systems (ICRIIS) (pp. 49-54). IEEE. http://doi.org/10.1109/ICRIIS.2013.6716684

Roselino, J. E. (2006). A Indústria de Software: o "modelo brasileiro" em perspectiva comparada. Universidade Estadual de Campinas.

Sharma, D. D., \& Blomstermo, A. (2003). The internationalization process of Born Globals: a network view. International Business Review, 12(6), 739-753. http://doi.org/10.1016/j.ibusrev.2003.05.002

Wazlawick, R. (2013). Engenharia de Software: conceitos e práticas. Rio de Janeiro: Elsevier. Retrieved from https://books.google.com/ books?id=Qtg4VUkE0V0C\&pgis=1

Yin, R. K. (2013). Case study research: design and methods. (5th ed.). Sage Publications. 